\title{
Hygrothermal Regulation of Brick Masonry of Nanjing City Wall by Plants
}

\section{Changchang Xia ${ }^{1}$, Zhenyi Kong ${ }^{2}$, Shuichi Hokoi ${ }^{3}$, Bo Ding ${ }^{4}$, Tianwen Wang ${ }^{5}$ and Yonghui $\mathbf{L i}^{6}$}

\author{
${ }^{1}$ School of Architecture, Southeast University, Nanjing, China, xia_2017@seu.edu.cn \\ ${ }^{2}$ School of Architecture, Southeast University, Nanjing, China, kongzhenyi@seu.edu.cn \\ ${ }^{3}$ School of Architecture Internationalization Demonstration, Southeast University, Nanjing, China, \\ hokoi@seu.edu.cn \\ ${ }^{4}$ Nanjing Bureau of Culture and Tourism, Nanjing, China, 347464717@qq.com \\ ${ }^{5}$ Nanjing City Wall Protection and Management Center, Nanjing, China, 77930380@qq.com \\ ${ }^{6}$ School of Architecture, Southeast University, Nanjing, China, liyonghui@seu.edu.cn
}

\begin{abstract}
Nanjing City Wall, one of the most important cultural heritages in China, has been damaged in a natural environment for centuries. Plants can be a candidate to regulate the micro-environment and mitigate the influence of local climates, which cannot be easily controlled by human efforts. Therefore, we examined the potential of the roadside trees along the City Wall to buffer the hygrothermal cycles that can deteriorate the City Wall. We surveyed the deteriorated state and measured the temperature and moisture content of the City Wall. Measured results showed smaller temperature fluctuation at shaded surface than the unshaded with a maximum temperature difference of $10.9^{\circ} \mathrm{C}$ in summer. The measured water content decreased with height. A coupled two-dimensional hygrothermal 'City Wall-plant' model was proposed to clarify the influence of the roadside trees on the hygrothermal distribution of the City Wall. The proposed city wall-plant hygrothermal model could predict the surface temperature and water content well.
\end{abstract}

Keywords: Heritage Conservation, City Wall, Plant Regulation, Hygrothermal Distribution, Deterioration.

\section{Introduction}

Nanjing City Wall, one of the most important cultural heritages in China, has a long history that can be traced back over 600 years. It is an ancient structure with abundant cultural heritage values, among which are inscriptions (Nanjing City Wall Protection and Management Centre, 2016) (Figure 1) that contain information about responsible organizations and persons on bricks. Nanjing City Wall was deteriorated due to efflorescence, peeling and cracking which damage surface inscriptions.

Related to conservation of cultural heritages, one key consideration is how to mitigate the effects of environmental fluctuations on wall materials. Nanjing City Wall has been exposed to climatic variations such as solar radiation, temperature, relative humidity, and rainfall. The humidity is strongly correlated with formation of the fungal communities that causes biodeterioration ( $\mathrm{Li}$, et al. 2020). Different ambient relative humidity conditions would result in various degrees of damage by the crystallization pressure of sodium sulphate (RodriguezNavarro and Eric, 1999). Moisture significantly reduces the compression strength of thebricks 
(Foraboschi and Vanin, 2014) and determines the degree of freeze-thaw damage based on temperature (Feng, et al. 2019).

With respect to green urban development, coverage with vegetation offers a potential solution. English ivy has been found to reduce the range and variability of wall-surface microclimates over diurnal, seasonal and annual timescales (Sternberg, et al. 2011) and reduce the frequency, duration, and severity of freezing events (Coombes, et al. 2018) at historic sites in England. Araoka, et al. (2017) investigated the deterioration pattern of the Nanjing City Wall and found that shaded brick walls with trees on their side were relatively well-preserved.

This study aims at evaluating the potential of the roadside trees along the wall to buffer the microclimate of Nanjing City Wall. First, the situation of Nanjing City Wall was investigated and the temperature and moisture content of the wall were measured. Second, a twodimensional hygrothermal 'City Wall-plant' model was developed to evaluate the influence of trees.
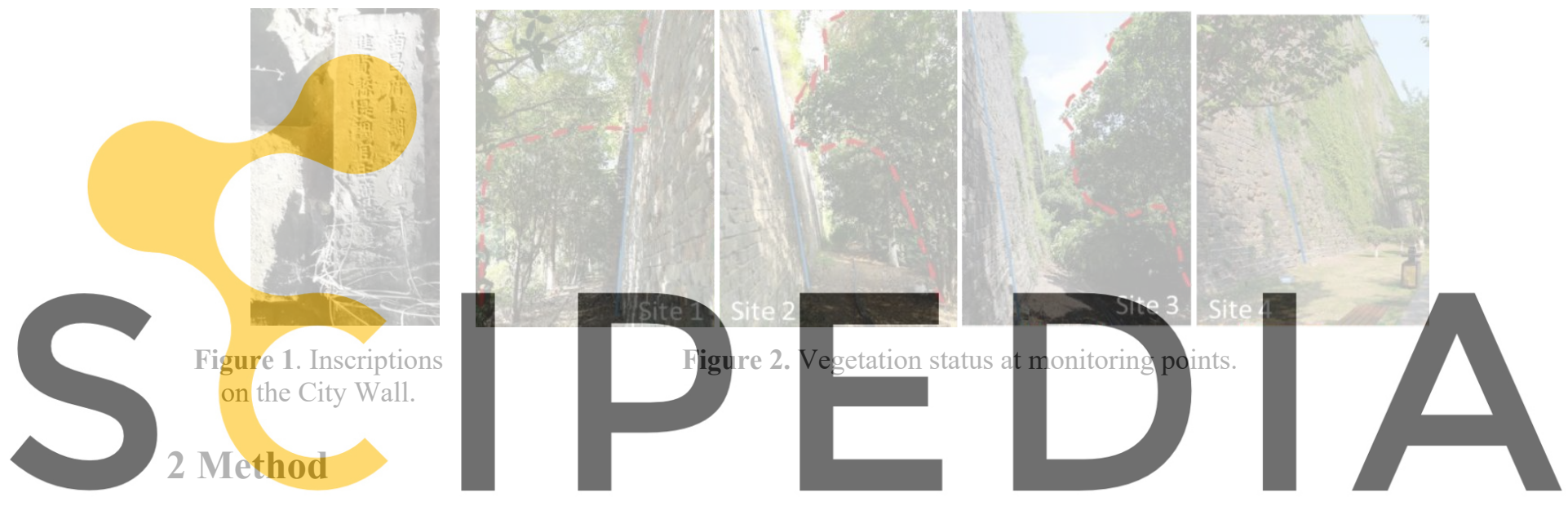

Register for free at https//www.scipedia.com to download the version without the watermark The measurements have been conducted around Jiefang gate( one gate at the northern part of City Wall). Two shaded walls (Sites 1and Site 2 ) and two unshaded wall (Site 3 and Site 4) were selected and been monitored from April 2019 to December 2019 (Figure 2). Air temperature and relative humidity under the canopy, surface temperature and water content of the City Wall were measured (Figure 3). The meteorological station was $800 \mathrm{~m}$ apart from the monitored sites. The monitored weather data included the air temperature, relative humidity, rainfall, and horizontal solar radiation.

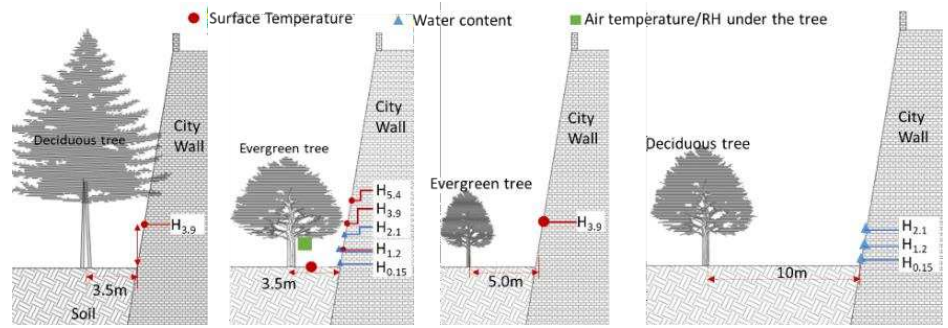

Figure 3. Outline of monitoring at each site. Monitoring period: Jun.- Dec. 2019 (temperature); Apr. - Dec. 2019 (water content). The heights of measured points are denoted as $\mathrm{H}_{0.15}(0.15 \mathrm{~m}), \mathrm{H}_{1.2}(1.2 \mathrm{~m})$, etc. 


\subsection{Simulation Model}

\subsubsection{City Wall}

The simultaneous transfer model of heat and water by Matsumoto. (1978) was adopted in this paper. The water chemical potential $\mu$ is used to express moisture state in this paper. The relationship between $\mu$ and temperature and relative humidity is as follows:

$$
\mu=R_{v} \operatorname{TIn}(h)
$$

Heat balance equation:

$$
c \rho \cdot \frac{\partial T}{\partial t}=\nabla\left[\left(\lambda+\lambda_{T g}^{\prime}\right) \nabla T+r \lambda_{T g}^{\prime} \nabla \mu\right]
$$

Moisture balance equation:

$$
\rho_{w}\left(\frac{\partial \Psi}{\partial \mu}\right)\left(\frac{\partial \mu}{\partial t}\right)=\varnothing\left[\lambda_{\mu}^{\prime}(\nabla \mu-g \boldsymbol{n})+\lambda_{T}^{\prime} \nabla T\right]
$$

\subsubsection{Plant model}

In our model, trees can reduce incident solar radiation to and the nocturnal radiation from the wall, and intercept the rainfall that dropped to vertical projection region (the ground and wall). Furthermore, the rainwater trapped by trees evaporated and removed heat from the plants. The model was based on the plant model by Kondou (1996). Figure 4 shows the thermal and

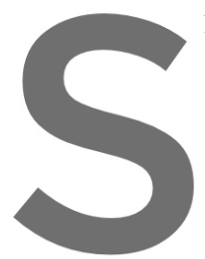
moisture network model
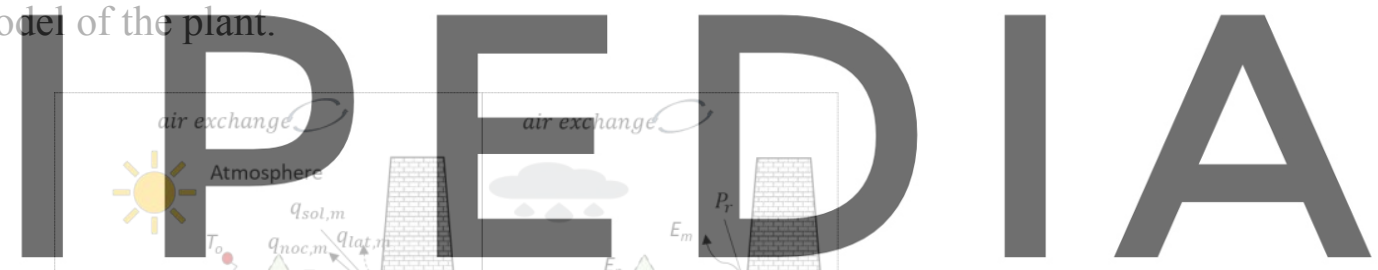

Register for free at https//www,scipedia.com to download the version without the watermark
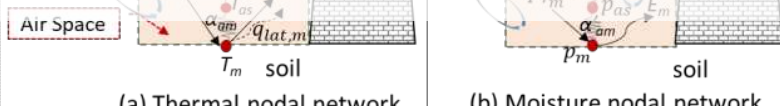

(a) Thermal nodal network

(b) Moisture nodal network

Figure 4. Thermal (a) and moisture (b) nodal networks of the plant-ground model.

\section{Results and Discussion}

\subsection{Measured Results}

\subsubsection{Weather data}

Figure 5 shows the weather data from Jan. 2019 to Dec. 2019. The temperature fluctuation was $42.6{ }^{\circ} \mathrm{C}\left(-2.6{ }^{\circ} \mathrm{C} \sim 40{ }^{\circ} \mathrm{C}\right)$, and the annual average temperature was $18.1{ }^{\circ} \mathrm{C}$. The relative humidity fluctuated between $15.8 \%$ and $100 \%$, and exceeded $90 \%$ for 1369 hours (Figure 5a). It rained more in the summer, followed by winter (Figure $5 \mathrm{c}$ ). The annual rainfall was 486.5 
$\mathrm{mm}$, much less than the average rainfall of $1206 \mathrm{~mm}$ for the last 10 years (Nanjing Bureau of Statistics. 2007-2017)).

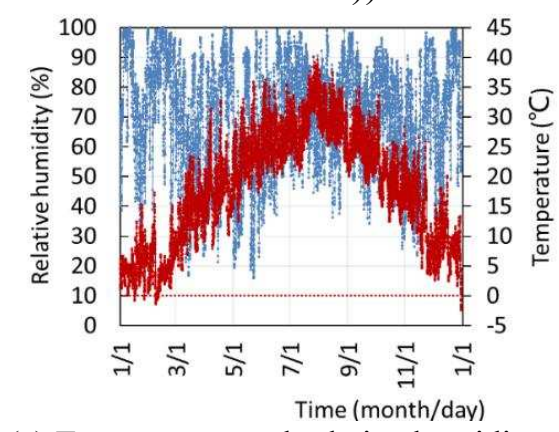

(a) Temperature and relative humidity

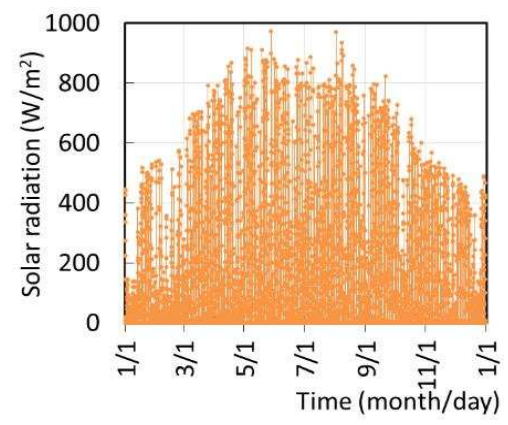

(b) Solar radiation

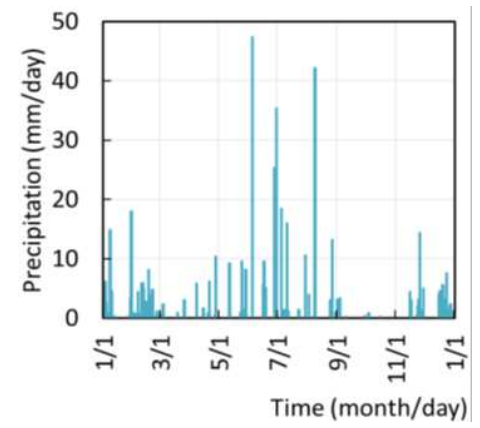

(c) Precipitation

Figure 5. Weather data (Jan. 2019-Dec. 2019).

\subsubsection{Air temperature and relative humidity under the canopy}

Figure 6 shows the measured air temperature and relative humidity under the canopy at Site 1 along with the meteorological (outdoor) data. During the monitoring period (Jun. 2019 - Dec. 2019), the temperature fluctuation of the air under the canopy and the outdoor air were $35.9^{\circ} \mathrm{C}$ $\left(1.8^{\circ} \mathrm{C} \sim 37.7^{\circ} \mathrm{C}\right)$ and $38.4{ }^{\circ} \mathrm{C}\left(1.6^{\circ} \mathrm{C} \sim 40^{\circ} \mathrm{C}\right)$, respectively. In summer, the temperature under the canopy was lower than the outdoor temperature for most time, with a $6.1{ }^{\circ} \mathrm{C}$ difference of

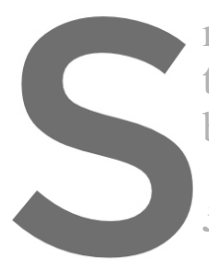
maximum temperature. On the contrary, the relative hum that of the outdoor values for the most time. The relative between $-27 \% \sim 8 \%$.

3.1.3 Surface temperature and water content of City Wall
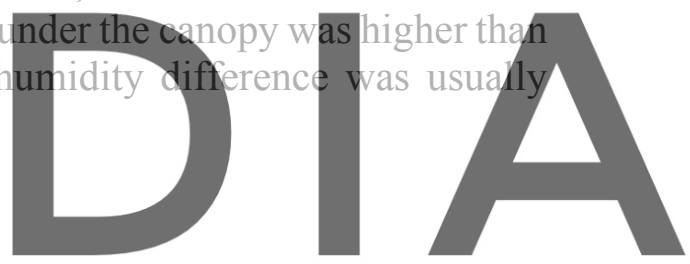

Figure 7 shows the measured surface temperatures at Site 1 (shaded $\mathrm{H}_{3.9}$ ) and Site 3 (unshaded

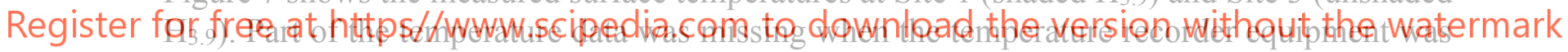

not powered. The temperature fluctuation at shaded $\mathrm{H}_{3.9}$ was $33.2^{\circ} \mathrm{C}\left(3.2^{\circ} \mathrm{C} \sim 36.4^{\circ} \mathrm{C}\right)$, which was smaller than the temperature fluctuation of $43.7^{\circ} \mathrm{C}\left(3.6^{\circ} \mathrm{C} \sim 47.3^{\circ} \mathrm{C}\right)$ at shaded $\mathrm{H}_{3.9}$. In summer, almost the same daily minimum temperatures and large differences in the maximum values were seen on shaded and unshaded points. In winter, due to the low solar altitude, the unshaded $\mathrm{H}_{3.9}$ (Site 3 ) was partly shaded by trees. Then and the similar temperature fluctuation can be seen at shaded (Site 1) and unshaded $\mathrm{H}_{3.9}$ (Site 3).

Figure 8 shows the average water content of 10 bricks at Site 2 and Site 4 . Due to lawns on the south side of Site 4 with regular irrigation in summer, this may result in increased water content of the wall. Therefore, this paper compares the water content fluctuation in two cases, separately. The results show the water content decreased with height, while the water content at $\mathrm{H}_{2.1}$ was higher than at $\mathrm{H}_{1.2}$ in Site 4 . It may be due to different water absorption and storage capacity of bricks and reduction of the evaporation rate by herbaceous plant at $\mathrm{H}_{2.1}$, and needed to be further studied. During the monitoring period, the water content of each height was obviously affected by rainfall. The water content was higher in rainy season (July and August), while lower in arid season (September and October). 


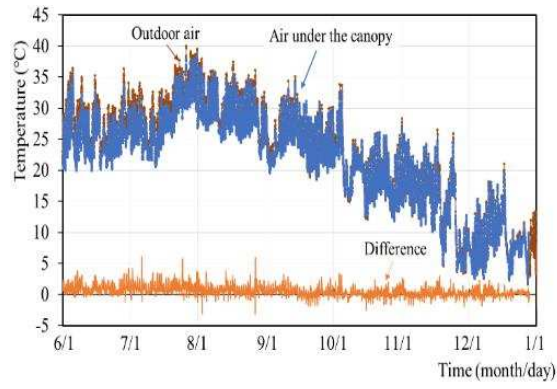

(a) Temperature

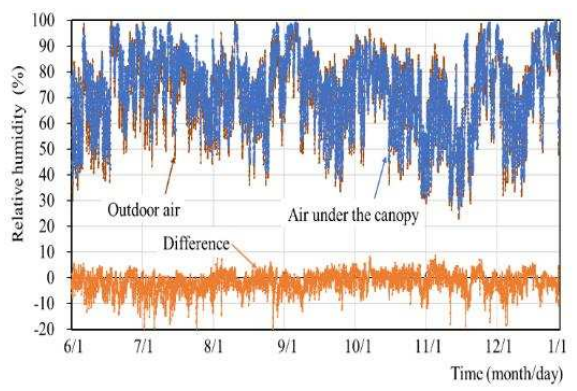

(b) Relative humidity

Figure 6. Temperature (a) and relative humidity (b) under tree and at meteorological station (Jun. 2019 - Dec. 2019) (Difference $=$ Outdoor air - Air under the tree).

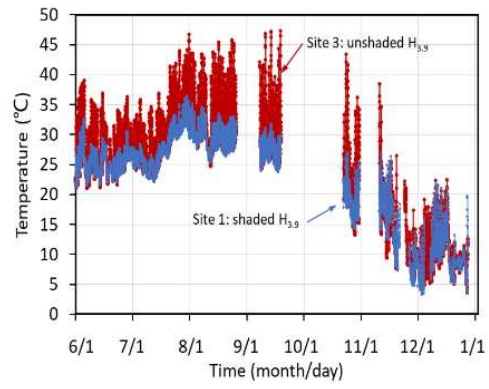

Figure 7. Measured surface temperatures on shaded and unshaded surfaces (Jun. 2019 - Dec. 2019).

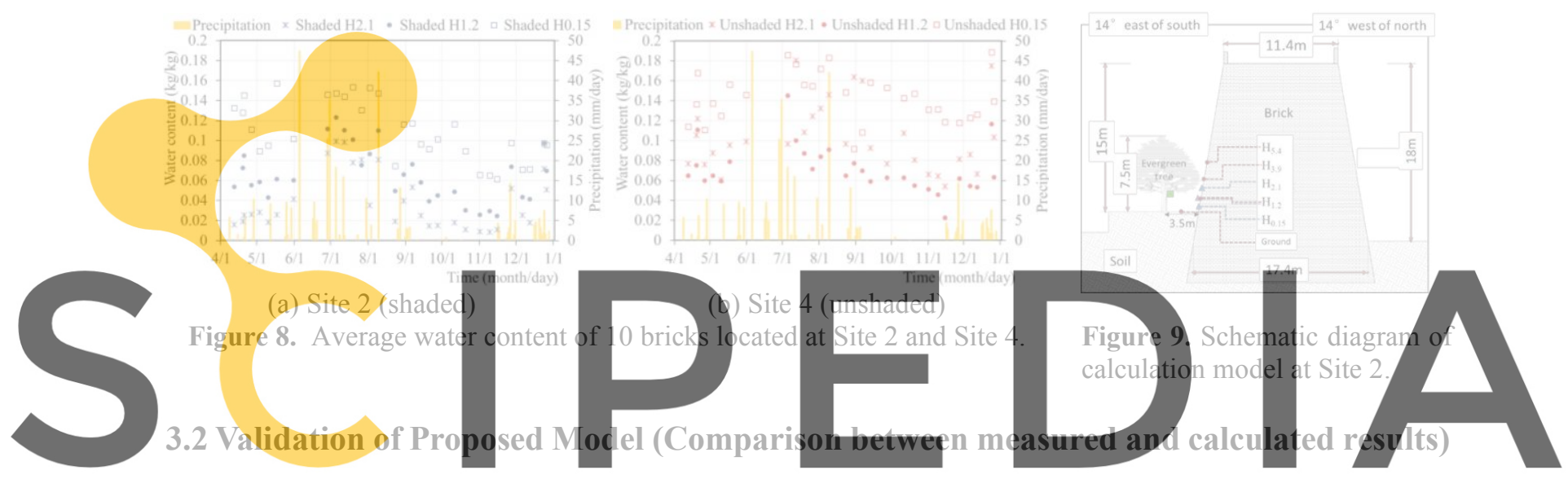

Figure 9 shows schematic diagram of a two-dimensional 'City Wall-plant' model. It is set up

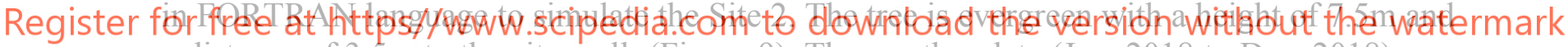
a distance of $3.5 \mathrm{~m}$ to the city wall (Figure 9). The weather data (Jan. 2018 to Dec. 2018) was repeatedly used for 10 - years calculation as the boundary condition. Then the calculation was conducted with meteorological data in 2019 for one year, and the calculated results were analysed.

Figure 10 shows the measured and simulated surface temperatures at three points $\mathrm{H}_{1.2}, \mathrm{H}_{3.9}$, and $\mathrm{H}_{5.4}$ on the south facade at Site 2. A linear regression analysis was performed with the measured and simulated results, and a good correlation was obtained with slopes 1.00, 0.98, and 0.97 and goodness-of-fit $0.99,0.98$, and 0.96 at $\mathrm{H}_{1.2}, \mathrm{H}_{3.9}$, and $\mathrm{H}_{5.4}$, respectively. Figure 11 shows the measured and simulated water content at three heights $\left(\mathrm{H}_{0.15}, \mathrm{H}_{1.2}\right.$, and $\left.\mathrm{H}_{2.1}\right)$. The calculated water content reproduced the time profile of the measured results. The water content assumed a peak value during rainfall, then gradually decreased probably due to evaporation and water movement in the wall. The mean absolute error (MAE) was used to analyse the consistency of measured and simulated values. The MAE at three heights $\mathrm{H}_{0.15}, \mathrm{H}_{1.2}$, and $\mathrm{H}_{2.1}$ was $0.029 \mathrm{~m}^{3} / \mathrm{m}^{3}, 0.036 \mathrm{~m}^{3} / \mathrm{m}^{3}, 0.035 \mathrm{~m}^{3} / \mathrm{m}^{3}$, respectively. 
It can be concluded that the simulated temperatures and water content agreed well with the measured results in unshaded case. Thus, the proposed 'City Wall-plant' model can be used to examine the influence of the surrounding trees on the hygrothermal fluctuations and weathering of City Wall.

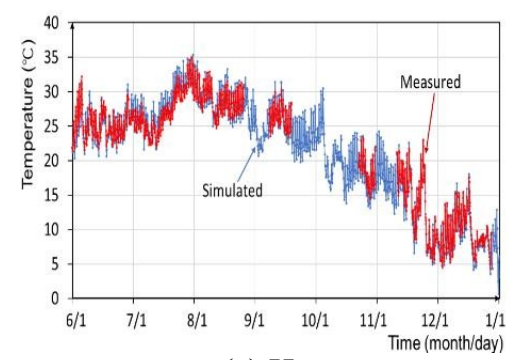

(a) $\mathrm{H}_{1.2}$

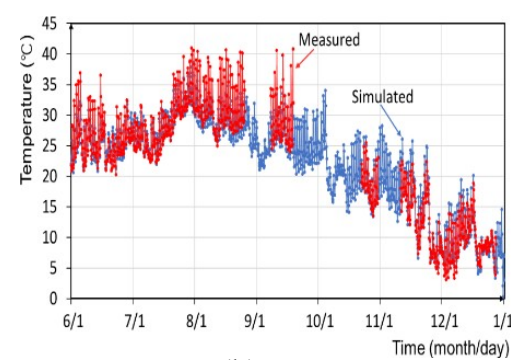

(b) $\mathrm{H}_{3.9}$

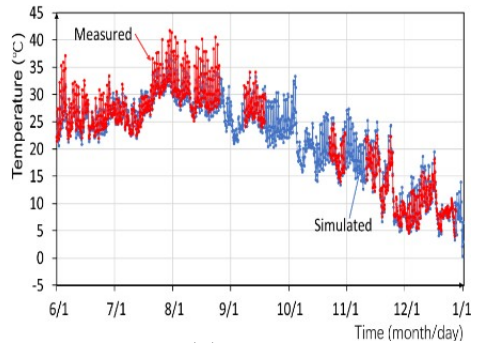

(c) $\mathrm{H}_{5.4}$

Figure 10. Comparison of the measured and simulated surface temperatures at three heights

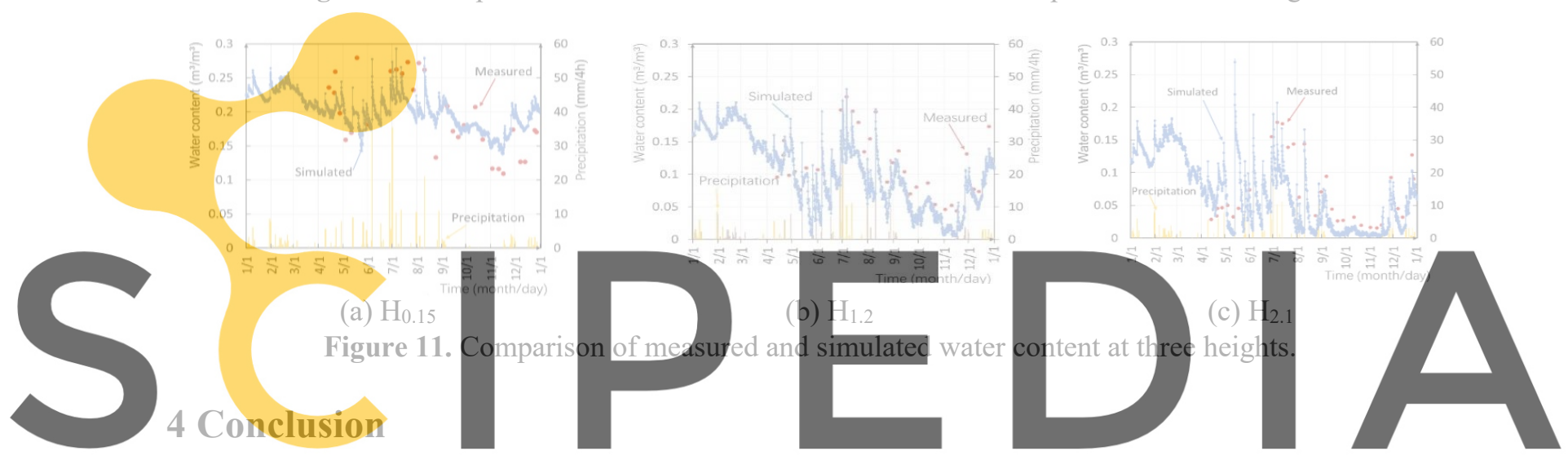

This study investigated the influence of trees on hygrothermal performance of Nanjing City

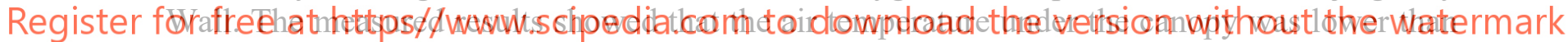
the outdoor air. The temperature fluctuation at shaded surface was smaller than the unshaded one, and the maximum temperature in shaded case was $6.1{ }^{\circ} \mathrm{C}$ lower than the unshaded in summer. The measured water content decreased with height.

The proposed 'City Wall-plant' model was validated through the comparison between measured and calculated results. Then the model can be used to analyse the trees' impact on the microclimate and surface weathering of Nanjing City Wall.

\section{Acknowledgement}

This research has been funded by the National Nature Science Foundation of China (Grant No. 51878140); the China National Key R\&D Program during the 13th Five-year Plan Period (Grant No. 2019YFC1520901); Jiangsu Provincial Cultural Research Project (2017SK01). This work was also supported by Nanjing City Wall Protection and Management Canter.

\section{ORCID}

Changchang Xia: https://orcid.org/0000-0002-5104-0307

Zhenyi Kong: https://orcid.org/0000-0002-7121-7085 
Shuichi Hokoi: https://orcid.org/0000-0002-3372-000X

Bo Ding: https://orcid.org/0000-0003-2356-9286

Tianwen Wang: https://orcid.org/0000-0003-3018-0762

Yonghui Li: https://orcid.org/0000-0001-9030-5358

\section{References}

Araoka, W., Hokoi, S., Ogura, D., Iba, C., Li, Y. and Hu, S. (2017). Deterioration and Preservation of City Wall in Nanjing. Energy Procedia, 132, 945-950. 10.1016/j.egypro.2017.09.734

Coombes, M.A., Viles, H.A. and Zhang, H. (2018). Thermal blanketing by ivy (Hedera helix L.) can protect building stone from damaging frosts. Scientific Reports, 8(1), 9834. 10.1038/s41598-018-28276-2

Feng, C., Roels, S. and Janssen, H. (2019). Towards a more representative assessment of frost damage to porous building materials. Building and Environment, 164, 106343. https://doi.org/10.1016/j.buildenv.2019.106343

Foraboschi, P. and Vanin, A. (2014). Experimental investigation on bricks from historical Venetian buildings subjected to moisture and salt crystallization. Engineering Failure Analysis, 45, 185-203. https://doi.org/10.1016/j.engfailanal.2014.06.019

Li, Y., Feng, Y., Kong, Z. and Hokoi, S. (2020). Optimization and Assessment of the Protective Shed of the Eastern Wu Tomb Energies, 13, 1652.

Matsumoto, M. (1978). Simultaneous Heat and Moisture Transfer and Moisture Accumulation in Building Materials. Kyoto, Japan: Kyoto University.

Nanjing Bureau of Statistics http://tjj.nanjing.gov.cn/. 2007-2017

Nanjing City Wall Protection and Management Centre. (2016). Inscription world Nanjing city wall brick (in Chinese). Nanjing: Nanjing Press.

Rodriguez-Navarro, C. and Eric, D. (1999). Salt Weathering: Influence of Evaporation Rate, Supersaturation and Crystallization Pattern,Earth Surface Processes and Landforms, 24(3).191-209

Sternberg, T., Viles, H. and Cathers surface microclimates ant 46(2), 293-297. https:

Kondou, S. (1996). Meteorolo (in Japanese): Asakur bookstor
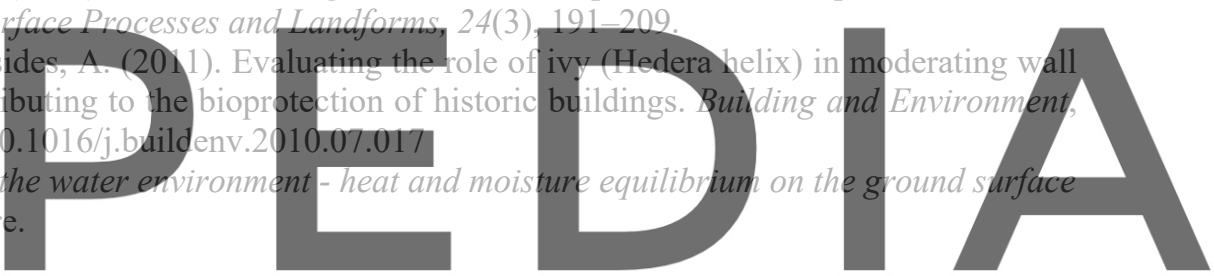

Appendix A. Nomenclature

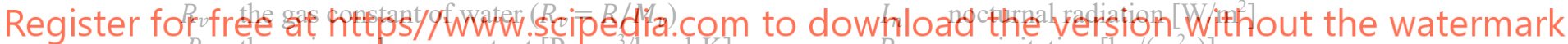

$R$ the universal gas constant $\left[\mathrm{Pa} \cdot \mathrm{m}^{3} / \mathrm{kmol} \cdot \mathrm{K}\right.$ ]

$M_{v}$ molar weight of water $[\mathrm{kg} / \mathrm{kmol}]$

$h$ the relative humidity.

$\rho_{w} \quad$ water density $\left[\mathrm{kg} / \mathrm{m}^{3}\right]$

$\Psi$ the volumetric water content $\left[\mathrm{m}^{3} / \mathrm{m}^{3}\right]$

$n$ unit vector in the direction of gravity

$q$ heat flux $\left[\mathrm{W} / \mathrm{m}^{2}\right]$

$j$ total (liquid and vapor) water flux $\left[\mathrm{kg} /\left(\mathrm{m}^{2} \cdot \mathrm{s}\right)\right]$

$T$ temperature [K]

$p \quad$ vapor pressure $[\mathrm{Pa}]$

$p_{\text {sat }}$ saturation vapor pressure $[\mathrm{Pa}]$

$\mu \quad$ water chemical potential $[\mathrm{J} / \mathrm{kg}]$

$\gamma$ transmission coefficient of solar radiation by canopy

$\gamma \quad[-]$

$\gamma^{\prime} \quad$ transmittance of plants to rainwater [-]

$A$ absorption coefficient of solar radiation [-]

$\varepsilon \quad$ longwave emissivity [-]

$\alpha$ heat transfer coefficient $\left[\mathrm{W} /\left(\mathrm{m}^{2} \cdot \mathrm{K}\right)\right]$

\section{P}

$P_{r_{m}}$ the rainfall to ground $\left[\mathrm{kg} / \mathrm{m}^{2} \mathrm{~s}\right]$

$R$ thermal resistance $\left[\left(\mathrm{m}^{2} \mathrm{~K}\right) / \mathrm{W}\right]$

$R^{\prime} \quad$ moisture resistance $\left[\left(\mathrm{m}^{2} \cdot \mathrm{K} \cdot \mathrm{Pa}\right) / \mathrm{kg}\right]$

$c \rho$ specific heat capacity $\left[\mathrm{J} /\left(\mathrm{m}^{3} \mathrm{~K}\right)\right]$

$c_{a}^{\prime} \quad$ moisture capacity of the air $\left[\mathrm{kg} /\left(\mathrm{m}^{3} \mathrm{~Pa}\right)\right]$

$V \quad$ volume $\left[\mathrm{m}^{3}\right]$

$\rho \quad$ density $\left[\mathrm{kg} / \mathrm{m}^{3}\right]$

$\beta \quad$ evaporation efficiency of vegetation [-]

$C_{h} \quad$ coefficient of volume movement [-]

$U$ wind speed $[\mathrm{m} / \mathrm{s}]$

$S_{h} \quad$ specific humidity $[\mathrm{kg} / \mathrm{kg}]$

$S$ area[m $\left.\mathrm{m}^{2}\right]$

$r \quad$ heat of phase change of water [J/kg]

$g$ gravitational acceleration $\left[=9.8 \mathrm{~m} / \mathrm{s}^{2}\right]$

$E_{p} \quad$ rainfall trapped by trees $\left[\mathrm{kg} /\left(\mathrm{m}^{2} \mathrm{~s}\right)\right]$

$E_{t}$ evapotranspiration of plants $\left[\mathrm{kg} / \mathrm{m}^{2} \mathrm{~s}\right]$ 
$\alpha^{\prime} \quad$ water vapor transfer coefficient $\left[\mathrm{kg} / \mathrm{m}^{2} \mathrm{sPa}\right]$

$\alpha_{\mu}^{\prime} \quad$ water vapor transfer coefficient under the gradient of water chemical potential $\left[\mathrm{kg} / \mathrm{m}^{2} \cdot \mathrm{s} \cdot(\mathrm{J} / \mathrm{kg})\right]$

$\alpha_{T}^{\prime} \quad$ water vapor transfer coefficient under the gradient of temperature $\left[\mathrm{kg} / \mathrm{m}^{2} \cdot \mathrm{s} \cdot \mathrm{K}\right]$

$\lambda$ thermal conductivity $[\mathrm{W} / \mathrm{m} \cdot \mathrm{K}]$

$\lambda_{\mu}^{\prime} \quad$ water (liquid and vapor) conductivity under the

$\lambda_{\mu}^{\prime}$ gradient of water chemical potential $[\mathrm{kg} / \mathrm{m} \cdot \mathrm{s} \cdot(\mathrm{J} / \mathrm{kg})]$

$\lambda_{T}^{\prime} \quad$ water (liquid and vapor) conductivity under the gradient of temperature $[\mathrm{kg} / \mathrm{m} \cdot \mathrm{s} \cdot \mathrm{K}]$

$\lambda_{T g}^{\prime} \quad$ Water vapor conductivity of the solid material

$\lambda_{T g}$ under the gradient of temperature $[\mathrm{kg} /(\mathrm{m} \cdot \mathrm{s} \cdot \mathrm{K})]$

$\lambda_{\mu g}^{\prime} \quad$ Water vapor conductivity under the gradient of

$\lambda_{\mu g}$ water chemical potential $[\mathrm{kg} /(\mathrm{m} \cdot \mathrm{s} \cdot(\mathrm{J} / \mathrm{kg}))]$

$I_{S} \quad$ solar radiation $\left[\mathrm{W} / \mathrm{m}^{2}\right]$
$E_{m}$ evaporation from material (wall or ground) surface $\left[\mathrm{kg} / \mathrm{m}^{2} \mathrm{~s}\right]$

\section{Subscripts}

a air

outdoor

surface

canopy

air space

material (wall or ground)

solar radiation

nocturnal radiation

latent heat

air exchange

the outdoor air -canopy surface

the canopy-air space surface

the air space-material (wall or ground)

surface

\section{Appendix B. Plant model}

The plant model was based on the plant model by Kondou (1996). The equations of heat and moisture balance in plant model are as follows.

1. Heat balance of the canopy cell:

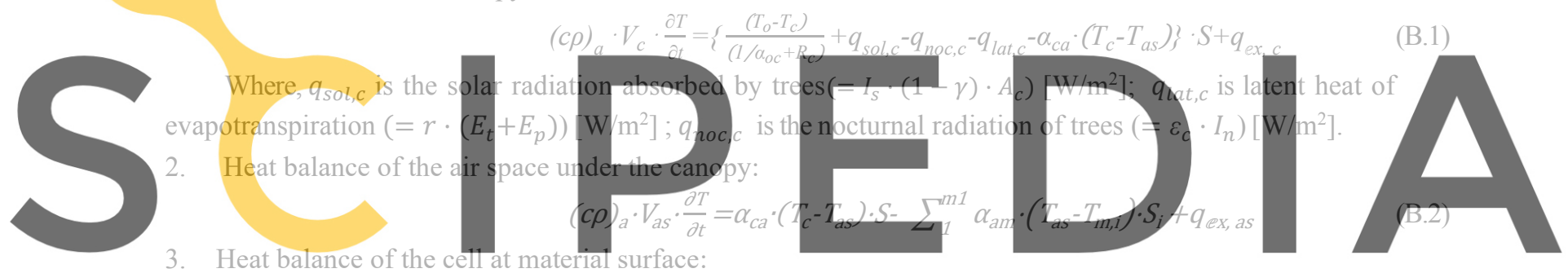

3. Heat balance of the cell at material surface:

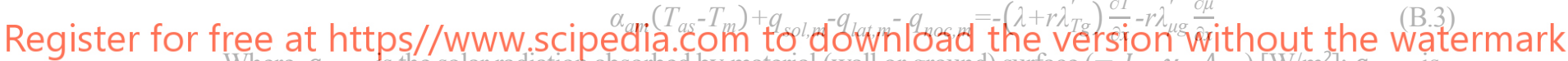

Where, $q_{s o l, m}$ Is the solar radiation absorbed by material (wall or ground) surface $\left(=I_{S} \cdot \gamma \cdot A_{m}\right)\left[\mathrm{W} / \mathrm{m}^{2}\right] ; q_{l a t, m}$ is

latent heat of evaporation from material (wall or ground) surface $\left(=r \cdot E_{m}\right)\left[\mathrm{W} / \mathrm{m}^{2}\right] ; q_{\text {noc, } m}$ is nocturnal radiation of material (wall or ground) surface $\left(=\varepsilon_{m} \cdot I_{n}\right)\left[\mathrm{W} / \mathrm{m}^{2}\right]$.

4. Moisture balance of the canopy cell:

$$
C_{a}^{\prime} \cdot V_{c} \frac{\partial p}{\partial t}=\left\{\frac{\left(p_{o}-p_{c}\right)}{\left(1 / \alpha_{o c}^{\prime}+R_{c}^{\prime}\right)}+E_{p}+E_{t}-\alpha_{c a}^{\prime} \cdot\left(p_{c}-p_{a s}\right)\right\} \cdot S+j_{e x, c}
$$

5. Moisture balance of the air space under the canopy:

$$
C_{a}^{\prime} \cdot V_{a s} \frac{\partial p}{\partial t}=\sum_{1}^{m 2} E_{m, i} \cdot S_{i}+j_{e x, a s}
$$

6. Moisture balance of the cell at material surface:

$$
\begin{gathered}
\gamma^{\prime} \cdot P_{r}-E_{m}=-\lambda_{\mu}^{\prime} \cdot\left(\frac{\partial \mu}{\partial x}-g\right)-\lambda_{T}^{\prime} \frac{\partial T}{\partial x} \\
E_{t}=\rho \beta C_{h} U \cdot\left(\frac{\partial S_{h}}{\partial P}\right) \cdot\left(p_{s a t}\left(T_{c}\right)-p_{o}\right) \\
E_{P}=\left(1-\gamma^{\prime}\right) \cdot P_{r} \\
E_{m}=\alpha_{\mu}^{\prime}\left(\mu_{m}-\mu_{a s}\right)+\alpha_{T}^{\prime}\left(T_{m}-T_{a s}\right)
\end{gathered}
$$

Where, 